\title{
Control de la tenacidad de los hormigones reforzados con fibras usando el ensayo de doble punzonamiento (ensayo barcelona)
}

\section{Q uality control of fiber reinforced concretes by mean of double punshing test (barcelona test)}

\author{
Sergio Carmona Malatesta *1, Antonio Aguado de Cea**, Climent Molins Borrell**, Manuel Cabrera Contreras* \\ * Universidad Técnica Federico Santa M aría, Valparaíso, CHILE \\ ** U niversitat Politècnica de Catalunya, Barcelona, ESPAÑ A \\ Fecha de recepción: 30/ 04/2009 \\ Fecha de aceptación: 20/ 07/2009 \\ Resumen \\ PAG. $119-140$
}

\begin{abstract}
Tradicionalmente, se utiliza el ensayo de vigas prismáticas sometidas a flexión para caracterizar la resistencia y el comportamiento en el régimen post fisuración del hormigón reforzado con fibras (HRF). Sin embargo, estos ensayos presentan una alta dispersión en sus resultados cuestionando su empleo para el control sistemático del HRF en obras; tienen, además el inconveniente de tratarse de ensayos complejos que requieren de probetas pesadas y de personal de laboratorio altamente calificado. Alternativamente, se ha propuesto el uso de otros ensayos normalizados de tracción directa e indirecta para realizar la caracterización de propiedades de los HRF, pero éstos han resultado ser muy complejos de ejecutar, sin obtener grandes mejoras en relación a la alta dispersión de los resultados. Con la finalidad de solucionar esta serie de inconvenientes, se ha propuesto el uso de un ensayo de tracción indirecta basado en una configuración del ensayo de doble punzonamiento, al que se ha denominado "Ensayo Barcelona". Este ensayo requiere de probetas de pequeñas dimensiones, con una alta superficie específica de fractura, permitiendo obtener valores representativos de la resistencia y de la tenacidad del material, con un coeficiente de variación de los resultados inferior al 13\%, valor que es considerablemente menor a los alcanzados con otras metodologías experimentales. En este artículo se presentan los resultados de diferentes campañas experimentales, que permiten validar el uso del ensayo Barcelona como una metodología experimental adecuada para la sistemática caracterización del HRF en obras.
\end{abstract}

Palabras Clave: Hormigón reforzado con fibras, tenacidad de HRF, ensayo Barcelona, ensayo de doble punzonamiento, control de HRF

Abstract

Traditionally, flexural testing of prismatic beams is used to characterize the strength and behavior in post - cracking regime of fiber - reinforced concretes (FRC). These tests exhibit a high dispersion in their results, and therefore invalidate the use of such tests for the systematic control of FRCs works. Also, they have the disadvantage of being complex tests, which require heavy specimens and highly qualified staff. The use of other standard tests of direct and indirect tensile strength has also been intended, which have proved very complex to implement and also have high dispersion. Aiming to solve this set of problems, an indirect tensile test based on the configuration of double punching test, called the Barcelona test, has been proposed to control tensile behavior of FRC. This test requires smaller specimens, with a high specific surface of fracture, allowing to obtain values representative of strength and toughness of materials, with considerably less dispersion than other experimental methodologies. This paper presents the results of different experimental campaigns, which validate the use of Barcelona test as a suitable methodology to systematic characterization FRC in works.

Keywords: Fiber reinforced concrete, Toughness of FRC, Barcelona test, D ouble - punching test, FRC control

\section{Introducción}

Durante las últimas décadas se ha producido un gran desarrollo en la industria de la construcción, que ha alcanzado no sólo a las técnicas de diseño y de cálculo, sino también a la tecnología del hormigón y al propio hormigón. Dentro de estas nuevas tecnologías se encuentra en un lugar muy destacado el empleo de fibras con el objeto de reforzar o armar el hormigón.

\section{Introduction}

During the last decades the construction industry has undergone a great development, that has reached not only the calculation and design techniques, but also the concrete technology and the concrete itself. Within these new technologies fiber occupies a very outstanding place with the intention of reinforcing concrete.

\footnotetext{
1 Autor de correspondencia / Corresponding author: E-mail: sergio.carmona@usm.cl
} 
En los hormigones reforzados con fibras (HRF), la tenacidad o capacidad de absorber energía ha sido reconocida como uno de los beneficios más importantes de la incorporación de fibras, mejorando el comportamiento ante la fractura, al impacto y a la fatiga (Gopalaratnam y G ettu, 1995).

Idealmente, Ia tenacidad de los HRF ante esfuerzos de tracción se debería cuantificar a través del ensayo de tracción directa o tracción uniaxial. Sin embargo, la dificultad de ejecución de este ensayo impide su uso, y por consiguiente, se recomienda determinar la tenacidad de los HRF a través del ensayo de flexión, el que, además de ser simple, representa las condiciones de carga de muchas aplicaciones de los HRF (ACl, 2008).

Actualmente, existe un gran número de normas y recomendaciones que establecen las condiciones de ensayo y parámetros para evaluar y cuantificar el efecto de la incorporación de fibras en el hormigón. U na de ellas, la norma ASTM C 1018 (ASTM International, 2002), especifica el ensayo de flexión con carga a los tercios, sobre probetas sin entalla, y la tenacidad es cuantificada a través de los índices de tenacidad y de resistencia a la primera fisura de los HRF. O tra recomendación ampliamente aceptada es el ensayo de flexión con carga central, sobre viguetas con entalla, recomendado por Rilem TC - 162 (Rilem, 2002), actualmente norma europea EN 14651(CEN, 2005). La ventaja de este método es que es simple y se controla a través del desplazamiento de apertura de los bordes de la fisura (CMOD por el inglés Crack M outh O pening Displacement), que asegura una propagación estable de la fisura, incluso para hormigón en masa. La curva carga - CMOD o bien la carga deflexión obtenidas a través de él pueden ser usadas para calcular las relaciones tensión-deformación o tensión - ancho de fisura y, de este modo, evaluar el efecto de la incorporación de las fibras.

El problema para proyectistas y contratistas es que los parámetros de comportamiento en el estado post - fisuración basados en el ensayo de vigas, generalmente ofrecen una exactitud muy baja. Ensayos realizados por Bernard (1999) dieron como resultado una media del coeficiente de variación en el comportamiento postfisuración del 15\%, para el índice ASTM $I_{30}$ (índice de tenacidad definido, en la norma ASTM C-1018, 1997. Éste se calcula dividiendo el área de la curva cargadeflexión hasta una deflexión de 15.5 veces la deflexión correspondiente a la primera fisura entre el área hasta la primera fisura). Situación similar sucede con el ensayo de flexión en tres puntos propuesto por Rilem,
In fiber reinforced concrete (FRC), toughness or energy absoption capacity has been recognized as one of the most important benefits of fiber addition, improving the cracking behavior, impact behavior, and fatigue (Gopalaratnam and Gettu, 1995).

Ideally, the FRC tensile toughness should be quantified through direct tensile test or uniaxial tension. Nevertheless, the difficulty of execution of this test prevents its use, and therefore, is recommended to determine the FRC toughness through flexural test, the one that, besides being simpler, represents the conditions of loading of many of the FRC applications (ACI, 2008).

Currently, there are a great number of standards and recommendations establishing the conditions of test and parameters to evaluate and to quantify the effect of the fiber incorporation in concrete. One of them, ASTM C 1018 (2002), specifies the flexural test with a loading at the thirds, on specimens without a notch, and the toughness is quantified through the indexes of toughness and to the first crack strength of FRC. Another recommendation widely accepted is the flexural test with central loading, on notched beams, recommended by Rilem TC - 162 (2002), at the moment European standard EN 14651 (CEN, 2005). The advantage of this method is that it is simple and is controlled through the crackmouth opening displacement (CMOD) that assures a stable propagation of the crack, even for cast in-situ concrete. The load - CMOD curve or the load - deflection obtained through it can be used to calculate the relations tensile - deformation or tensile - crack width and, in this way, to evaluate the effect of fibers addition.

The problem for designers and contractors is that the parameters of behavior in the post - crack state based on beams tests, generally offers a very low accuracy. Tests performed by Bernard (1999) gave as result an average of the coefficient of variation in the post-crack behavior of $15 \%$, for ASTM $I_{30}$ index (toughness defined index, in ASTM C-1018, 1997. This is calculated by dividing the area of the load-deflection curve until a deflection of 15.5 times the first crack deflection by the area until the first crack). Similar situation happens to the three point bending test proposed by Rilem, 
en el que se tiene una dispersión relativamente elevada en los resultados, entre el 20 - 30\%. Por tal razón, se presenta una dificultad para poder determinar los valores característicos del material.

Como alternativa, se ha utilizado el ensayo de flexión, según la normativa belga (NBN B 15-238, 1992), en el control de obras. No obstante, en el preámbulo de esa norma queda expresamente establecido que se trata de un ensayo de caracterización y que no es aplicable para el control sistemático del hormigón reforzado con fibras. Además, esta tipología de ensayos requiere de probetas relativamente pesadas, procedimientos experimentales complejos y sus resultados presentan dispersiones significativas, debido a que depende directamente del número específico de fibras que cosen la sección en donde se produce la fisura.

Considerando lo anterior y con el fin de disponer de un ensayo adecuado para el control sistemático de los HRF en obras, Aguado et al. (2005) han desarrollado un ensayo de tracción indirecta basado en el ensayo de doble punzonamiento (Double - Punching Test, DPT) propuesto por Chen (1970), el que se ha denominado ensayo Barcelona (BCN).

Este ensayo de doble punzonamiento, para el caso de hormigones convencionales no presenta ventajas significativas, con respecto a otros ensayos de determinación indirecta de la resistencia a tracción, como es el caso del ensayo brasileño (Molins et al., 2008a), por lo que no logró imponerse en su momento. Ahora bien, en el caso del comportamiento post pico de hormigones con fibras tiene numerosas ventajas frente a los otros ensayos existentes, por lo que parece procedente profundizar en su estudio dado que, por ejemplo, con menor peso da mayor superficie de rotura (o el equivalente en energía).

En este artículo se muestran las ventajas que presenta el ensayo de doble punzonamiento, también conocido como ensayo Barcelona, en comparación a diferentes ensayos recomendados internacionalmente para caracterizar las propiedades de los HRF, frente al control sistemático de hormigones reforzados con fibras en obras. Estas ventajas están validadas por extensas campañas experimentales, desarrolladas a partir de muestras obtenidas en obras realizadas en Barcelona en los últimos años y por ensayos realizados en la U niversidad Técnica Federico Santa María, en Valparaíso - Chile. in which a relatively high dispersion in the results, between 20 - 30\% is usually obtained. For such reason, a difficulty appears to be able to determine the characteristic values of the material.

As an alternative, the flexural test has been used, according to the Belgium Standard (N BN B 15238, 1992). However, in the introduction of that standard it is specifically established that is a characterization test and that is not applicable to the systematic control of the fibers reinforced concrete. In addition, this typology of tests requires of relatively heavy specimens, complex experimental procedures and their results present significant dispersions, because it directly depends on the specific number of fibers that bridge the crack.

Considering the above mentioned and with the purpose of having a test adapted to the systematic control of FRC performance, Aguado et al. (2005) have developed an indirect tensile test based on the double punching test (D ouble - Punching Test, DPT) proposed by Chen (1970), which has been denominated the Barcelona test (BCN).

This double punching test, for the case of conventional concretes does not present significant advantages, with respect to other tests of indirect determination of the tensile strength, as it is the case of the Brazilian test (Molins et al., 2008a), reason why it did not manage to prevail at the time. However, this same test, in the case of the post peak behavior of the concrete with fibers has numerous advantages against the other existing tests, reason why it seems proper to deepen in his study since, for example, with smaller weight it gives major cracking surface (or the equivalent in energy).

In this article the advantages that the double punching test presents, also known as Barcelona test are shown, in comparison to different tests recommended internationally to characterize the properties of FRC, in front of the systematic control of fibers reinforced concrete. These advantages are validated by extensive experimental program, developed from samples obtained in works realized in Barcelona in the last years and by tests realized in the Technical University Federico Santa Maria, in Valparaiso - Chile. 


\section{Ensayos para determinar la tenacidad de los HRF}

El ensayo a tracción uniaxial o tracción directa, es considerado como el modo más adecuado para determinar las propiedades de fractura de materiales frágiles. Sin embargo, es un ensayo difícil de ejecutar, con altas dispersiones en sus resultados, debido a la incapacidad de obtener de manera razonable distribuciones uniformes de tensiones a través de la fisura. Esto se puede atribuir a la heterogeneidad del material, a imperfecciones de la probeta y a excentricidades durante el proceso de carga. Además, existen otros inconvenientes tales como la sujeción de la probeta y la dificultad de asegurar la estabilidad del ensayo.

En los últimos años, el Comité Técnico de RILEM TC 162 (2002) ha propuesto un ensayo de tracción uniaxial sobre probetas con entallas. Un estudio realizado por Gettu y Barragán (2003) demuestra que es un método de ensayo robusto y representativo de la respuesta del material. Sin embargo, las tensiones post fisuración y los parámetros de tenacidad obtenidos en este ensayo presentan unos coeficientes de variación de aproximadamente un 30\%. Esta elevada dispersión que presentan los parámetros medidos hace que el ensayo sea de difícil aplicación como control sistemático del HRF (Saludes et al., 2007).

Normalmente, la tenacidad de los HRF se cuantifica a través del área bajo la curva carga - deflexión $(\mathrm{P}-\delta)$ obtenida en un ensayo de flexión de viguetas prismáticas (ACl, 2008), cargadas en el centro de la luz (Figura 1), como se indica en la norma europea EN 14651 (CEN, 2005) y la japonesa SF -4 (JSCE, 1984a) o dos cargas ubicadas a los tercios de la luz , como se establece en las normas ASTM C - 1018 (ASTM International, 2002) de Estados U nidos, UNE 83 - 510 (AEN O R, 1989) de España y NBN B 15 - 238 (NBN, 1992) de Bélgica. $\mathrm{O}$ tras recomendaciones basadas en ensayos de flexión, tanto sobre viguetas prismáticas como paneles, fueron presentadas in extenso por Gopalaratnam y Gettu (1995). En su artículo, estos autores concluyen que la determinación de la tenacidad de los HRF a través de los ensayos de viguetas sin entallas con cargas a los tercios, deben ser mejoradas considerando, entre otras, el uso de probetas prismáticas con relación largo/altura mayor que $5 \mathrm{y}$ recomiendan el uso de viguetas con entallas sometidas a flexión con carga en el centro, usando la CMOD como variable de control en un sistema de ensayo servo controlado de alta rigidez.

\section{Test to determine the toughness of FRC}

The direct tensile test, is considered as the more adapted way to determine the properties of fracture of brittle materials. Nevertheless, it is a test difficult to perform, with high dispersions in its results, due to the incapacity to obtain in a reasonable way uniform distributions of tension through the crack. This can be attributed to the heterogeneity of the material, to imperfections of the specimen and eccentricities during the loading process. In addition, other disadvantages exist such as the holding device of the specimen and the difficulty of assuring the stability of the test.

In the last years, the Technical Committee of RILEM TC 162 (2002) has proposed a flexural tensile test on specimens with notches. A research realized by $G$ ettu and Barragán (2003) demonstrates that it is a robust method and is a representative test of the answer of the material. N evertheless, the tensions post crack and the toughness parameters obtained in this test present coefficients of variation of approximately a $30 \%$. This high dispersion that presents the measured parameters causes that the test is of difficult application as a systematic control of FRC (Saludes et al., 2007).

Normally, the FRC toughness is quantified through the area under the load - deflection $(P-\delta)$ curved obtained in a prismatic beam bending test $(\mathrm{ACl}, 2008)$, loaded at the midspan (Figure 1), as indicated in the European standars EN 14651 (CEN, 2005) and the Japanese SF -4 (JSCE, 1984a) or two loads located to the thirds of the span, as it is established in ASTM C - 1018 standards (ASTM International, 2002) of the U nited States, UNE 83 - 510 (AEN O R, 1989) of Spain and NBN B 15 - 238 (N BN, 1992) of Belgium. O ther recommendations based on bending tests, as much as on prismatic beams as panels, were presented in extensive by Gopalaratnam and Gettu (1995). In their article, these authors conclude that the determination of the toughness of FRC through the beams tests without notches with loads to the thirds, must be improved considering, among others, the use of prismatic specimens with length /height ratio greater than 5 and recommend the use of beams with notches and thre-point bending, using the CMOD as control variable in a system of servo test - controlled of high rigidity. 


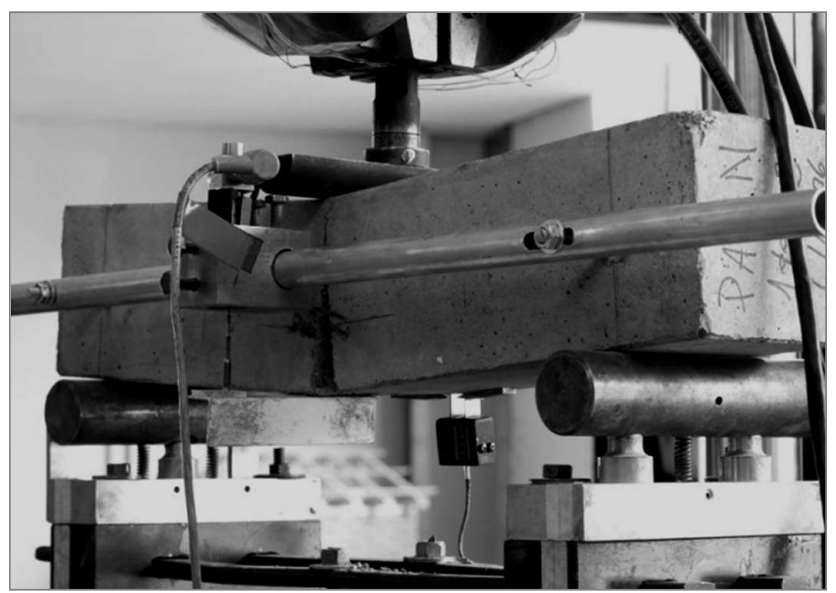

Figura 1. Ensayo de flexión de acuerdo a las recomendaciones de Gopalaratnam y Gettu (1995) Figure 1. Flexural Tet according to Gopalaratnam y G ettu (1995) recommendations

La tenacidad de los HRF también se puede determinar usando el ensayo de compresión, como se indica en la norma española UNE 83508 (AEN O R, 2004) y en la recomendación japonesa SF - 5 (JSCE, 1984b). En estos casos, durante el ensayo se debe registrar el desplazamiento axial de la probeta, por medio de tres transductores de desplazamiento montados en un compresómetro, el que se fija sobre la probeta, como se muestra en la Figura 2. Sin embargo, para grandes deformaciones, las mediciones se distorsionan a causa del agrietamiento que experimenta el manto del cilindro de hormigón en el rango post - fisuración.
The FRC toughness can be also determined using the compression test, as it is indicated in the Spanish standard UNE 83508 (AEN OR, 2004) and in the Japanese recommendation SF - 5 (JSCE, 1984b). In these cases, during the test the axial displacement of the specimen must be registered, by means of three mounted transducers of displacement in compressometer, that is attached on the specimen, as it is in Figure 2. N evertheless, for great deformations, the measurements are distorted because of the crack that experiences the surface of the concrete cylinder in the post - crack rank.

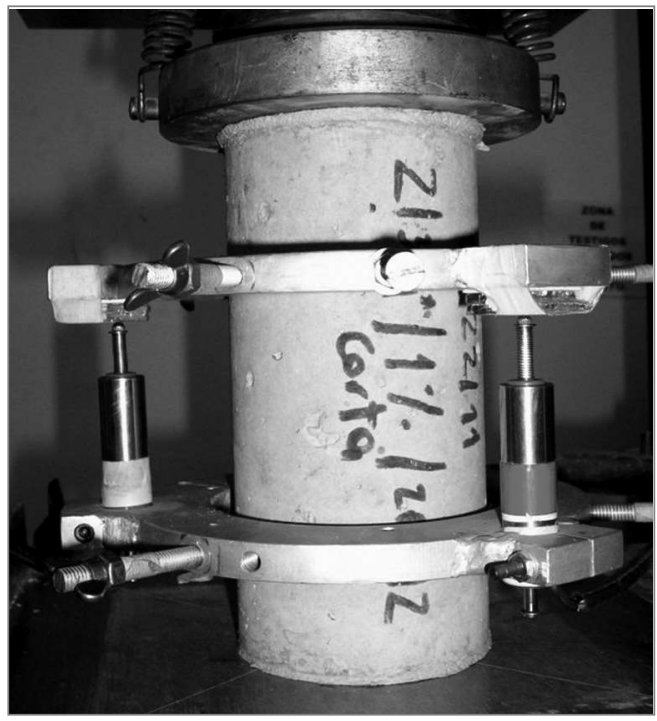

Figura 2. Montaje de un ensayo para determinar las propiedades de los HRF en compresión (Flores, 2005) Figure 2. Test setup to determine the properties of the compressive strength in FRC (Flores, 2005) 
Menos frecuente ha sido la cuantificación de la tenacidad a través del ensayo de tracción indirecta o ensayo brasileño. Éste es un método ampliamente aceptado para determinar en forma indirecta la resistencia a tracción uniaxial del hormigón, principalmente debido a que se puede ejecutar sobre probetas cilíndricas, moldeadas 0 testigos, cúbicas o prismáticas. Además, es un procedimiento muy simple y ha sido especificado por varias normas y recomendaciones, entre las que cabe señalar ASTM C - 496 (ASTM International, 2002), UNE 83306 (AEN O R, 1985), N Ch 1170 (IN N , 1977) y Rilem CP C6 (Rilem, 1994).

Los resultados de al gunos autores ( $N$ anni 1988; Nanni 1991; Cho et al., 1992) que han usado este ensayo para determinar la tenacidad de HRF, permiten concluir que la respuesta post - agrietamiento obtenida no representa el efecto de fibras satisfactoriamente, debido a que el estado tensional, especialmente en la zona de aplicación de la carga, no permite que las fibras dominen el comportamiento post - agrietamiento del material. Frente a esos resultados, este ensayo se ha considerado inapropiado para el hormigón reforzado con fibras básicamente por tres razones (Carmona et al., 1998):

(1) El área de carga para grandes deformaciones, como sucede en el estado de post - fisuración de probetas de $H R F$, aumenta continuamente conduciendo a un incremento en la carga incluso después de la fisuración de la matriz;

(2) el ensayo es inestable bajo el control de desplazamiento; $y$

(3) la considerable longitud de las probetas permite a la fisura iniciarse dentro de ella, dificultando la medición de la apertura de fisura y el control de estabilidad.

Con el propósito de solucionar los problemas observados en el ensayo de tracción indirecta y beneficiarse del uso de un procedimiento experimental altamente difundido y aceptado, que hace uso de una probeta estandarizada para el ensayo de compresión, Carmona et al. (1998) realizaron las siguientes mejoras (mostradas en la Figura 3): se redujo la longitud de la probeta; se limitó el área de carga, con el fin de mantener una anchura constante durante todo el ensayo; y los ensayos se realizaron en un sistema servo - controlado, usando el desplazamiento de la apertura de la fisura (COD) como variable de control durante el ensayo. Como se puede ver en la Figura 4, incorporando estas mejoras se han podido realizar ensayos brasileños estables,
The quantification of the strength through an indirect tensile test or Brazilian test has been less frequent. This is a method widely accepted to indirectly determine the resistance to uniaxial traction of the concrete, mainly because it is possible to be executed on cylindrical specimens, cubical or prismatic. In addition, it is a very simple procedure and has been specified by several standards and recommendations, among them it is possible to indicate ASTM C - 496 (2002), UNE 83306 (AEN OR, 1985), N Ch 1170 (1977) and Rilem CP C6 (1994).

The results of some authors ( $N$ anni 1988; Nanni 1991; Cho et al., 1992) that have used this test to determine the FRC strength, allows to conclude that the post - crack behavior obtained does not satisfactorily represent the fiber effect, because the tensile state, especially in the zone of application of the load, does not allow that the fibers dominate the post - crack behavior of the material. Against those results, this test has been considered unsuitable for the FRC basically for three reasons (Carmona et al., 1998):

(1) the load area for great deformations, as it happens in the of post - crack state of specimens of FRC, continuously increases leading to an increase in the load even after the crack of the matrix;

(2) the test is unstable under the displacement control; and

(3) the considerable length of the specimens allows the cracking to begin within itself, making more difficult the measurement of the crack opening and the stability control.

In order to solve the problems observed in the indirect tensile test and to benefit from the use of an experimental procedure highly spread and accepted, that uses a standardized specimen for the compressive test, Carmona et al. (1998) realized the following improvements (shown in Figure 3): the length of the specimen was reduced; the load area was limited, with the purpose of maintaining a constant width throughout the test; and the tests were realized in a servo system - controlled, using the crack opening displacement (COD) as control variable during the test. As it is possible to see in Figure 4, incorporating these improvements has made possible to perform of stable Brazilian tests, 
capaces de reflejar claramente la ventaja que conlleva la incorporación de fibras de acero en los hormigones de alta resistencia. Sin embargo, el ensayo resulta complejo y poco adecuado para ser utilizado como ensayo de control rutinario en obra. able to clearly reflect the advantage that entails the steel fiber incorporation in concretes of high strength. N evertheless, the test turns out complex and little suitable to be used as routine control test in work.

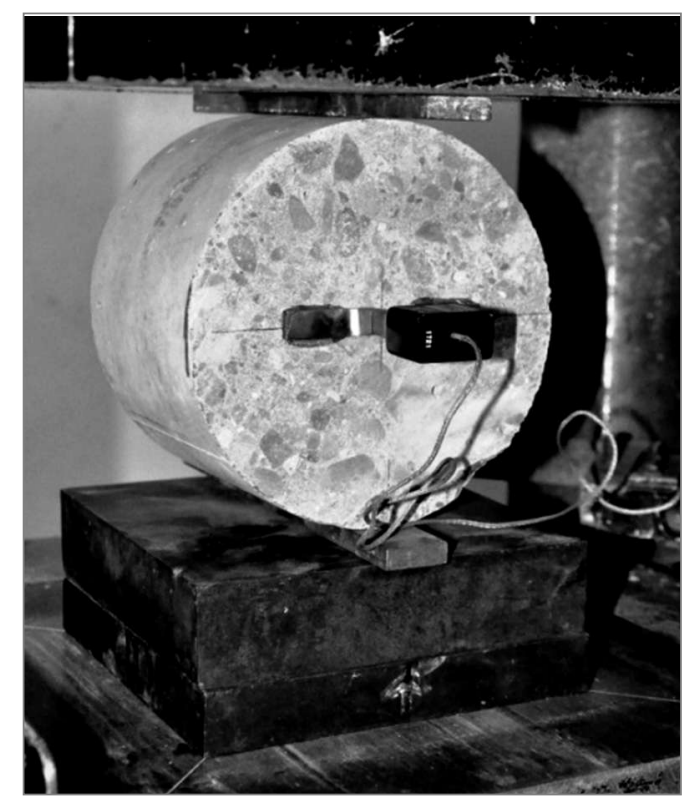

Figura 3. Ensayo brasileño realizado usando las modificaciones propuestas por Carmona et al. (1998) Figure 3. Brazilian test using the modifications proposed by Carmona et al. (1998)

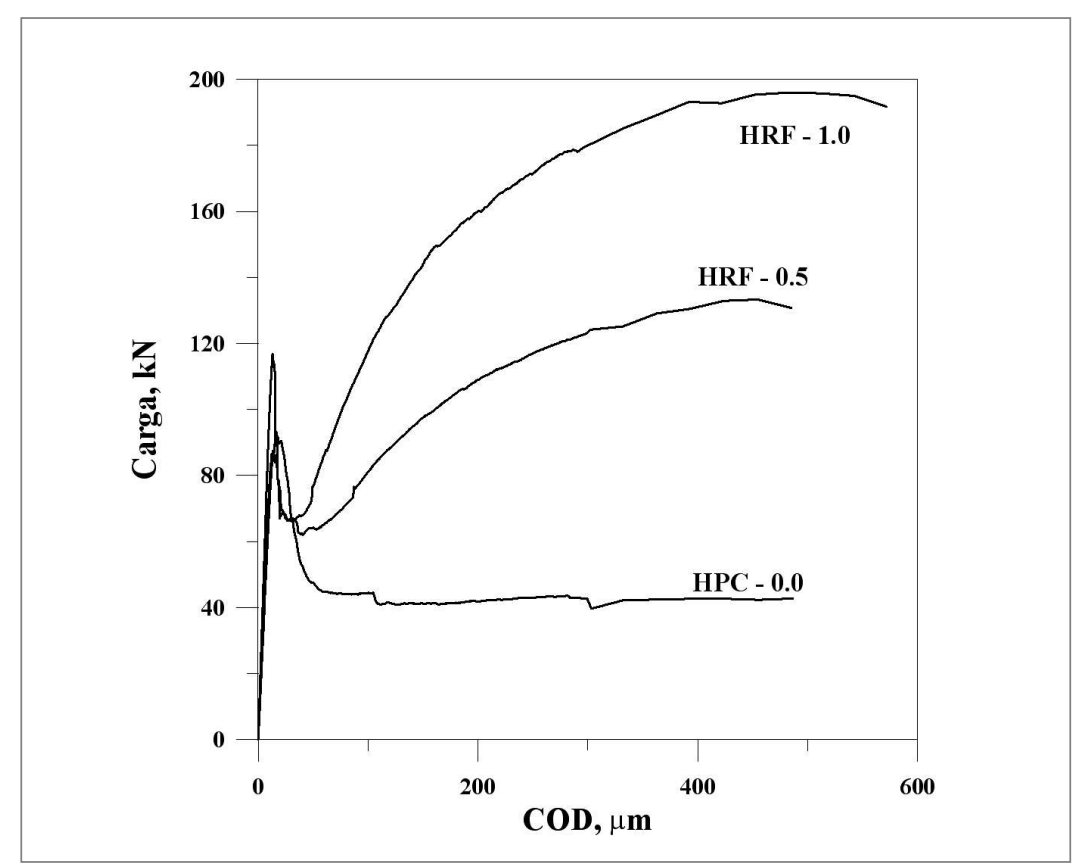

Figura 4. Resultados de los ensayos brasileños realizados por Carmona et al. (1998), sobre hormigones en masa (HPC - 0.0) y HRF

Figure 4. Results of the Brazilian tests realized by Carmona et al. (1998), on FRC and casts in-situ concrete (HPC - 0,0; HRF - 0.5; HRF - 1.0) 
Finalmente, el ensayo de la cuña o Wedge Splitting Test (WST), propuesto por Linsbauer y Tschegg (1986) y desarrollado más tarde por Brühwiler y Wittmann (2003), también ha sido utilizado para caracterizar la tenacidad de los HRF. Durante este ensayo, una cuña va cargando progresivamente un cubo de HRF, previamente entallado, como se muestra esquemáticamente en la Figura 5. El descenso de la cuña produce en la probeta un desplazamiento de apertura lateral de la entalla que origina la aparición y propagación estable de la fisura. Según Saludes et al. (2007), este es un método de ensayo interesante ya que presenta una serie de ventajas:

- No requiere de un equipo de ensayo sofisticado, puede ser realizado en máquinas habituales de ensayos mecánicos.

- El ensayo es estable.

- Gracias al tipo de configuración del ensayo el desplazamiento coincide con la apertura de fisura.

- El ensayo se puede realizar con muestras prismáticas o cilíndricas, permitiendo la posible extracción de muestras provenientes de estructuras existentes para su posterior control de calidad.

- Requiere cantidades inferiores de hormigón para realizar el ensayo, debido a que la muestra que se necesita es menor en comparación con otros métodos de ensayo, como por ejemplo en aquellos que usan como muestras vigas o paneles.

A pesar de que este ensayo ha sido exitoso para determinar las propiedades de fractura de hormigones normales, no hay mucha información disponible para el caso de los HRF. Una investigación de Löfgren et al. (2004), en la que ha comparado el WST con los ensayos de tracción uniaxial y de flexión en tres puntos, realizados siguiendo las recomendaciones de RILEM TC-162 TDF (2002) demuestra la aplicabilidad del ensayo W ST, con una dispersión general de los resultados inferior a la obtenida el ensayo de flexión en tres puntos.
Finally, the test of the wedge or Wedge - Splitting Test (W ST), proposed by Linsbauer and Tschegg (1986) and later developed by Brühwiler and Wittmann (2003), has also been used to characterize the strength of the FRC. During this test, a wedge is progressively loading a FRC specimen as it is schematically shown in Figure 5. The reduction of the wedge produces in the specimen a displacement of lateral opening of the notch that originates the appearance and stable propagation of the crack. According to Saludes et al. (2007), this is an interesting method of test since it presents a series of advantages:

- It does not require sophisticated equipment, it can be realized in regular testing machines.

- The test is stable.

- Thanks to the type of configuration, the displacement is in accordance with the crack opening.

- The test can be performed with prismatic or cylindrical specimens, allowing the possible extraction of samples of existing structures for its later quality control.

- It requires low concrete volume for the test to take place, because the sample needed is smaller in comparison with other test methods, as for example in those that use beams or panels as samples.

Although this test has been successful to determine the properties of normal concrete fracture, there is not much available information for the case of the FRC. An investigation of Löfgren et al. (2004), has compared the WST with the uniaxial tensile tests and the three-point bending test, realized following the recommendations of RILEM TC-162 TDF (2002) that demonstrates the applicability of the W ST test, with a general dispersion of the results which is inferior to the one obtained from the three-point bending test.

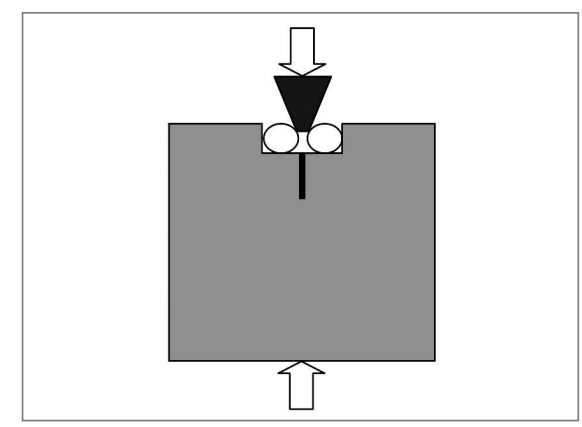

Figura 5. Esquema general del ensayo de la cuña Figure 5. General scheme of the wedge test 


\section{Ensayo de doble punzonamiento}

El ensayo de doble punzonamiento, propuesto por Chen (1970), consiste en someter compresión uniaxial a un cilindro mediante dos placas de carga cilíndricas de acero de diámetro menor (del orden de un cuarto del diámetro del cilindro ensayado), dispuestas concéntricamente por encima y por debajo de la probeta, como se muestra en la Figura 6.

\section{Doble punching test}

The double punching test, proposed by Chen (1970), consists of putting under uniaxial compression a cylinder by means of two cylindrical steel plates of smaller diameter (of the order of a quarter of the diameter of the test specimen), prepared concentrically superficially and below the specimen, as it is in Figure 6.

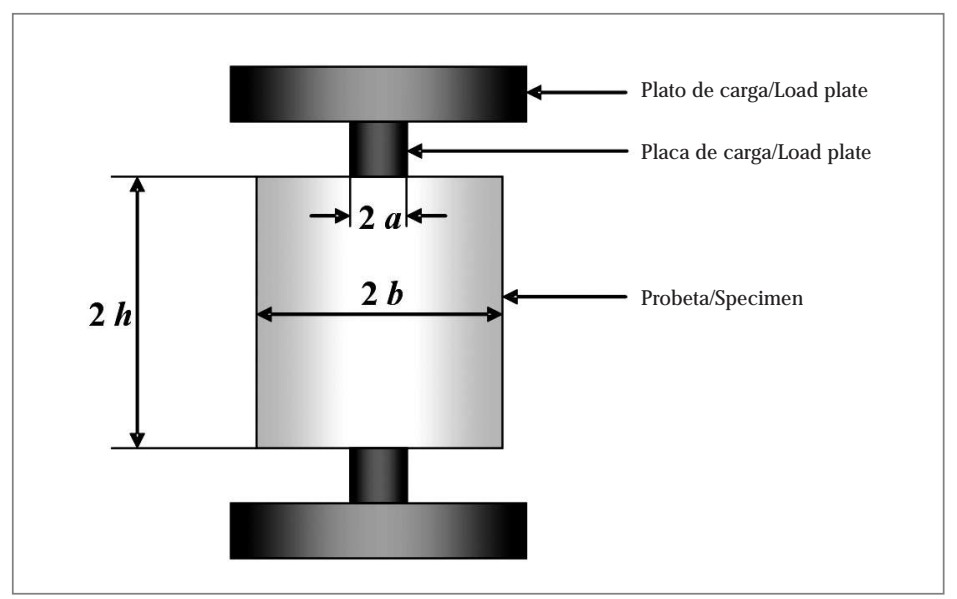

Figura 6. Configuración del ensayo de doble punzonamiento y definición de parámetros geométricos Figure 6 . Configuration of the double punching test and definition of geometric parameters

Durante el ensayo, la carga aplicada a través de las placas de acero produce una zona cónica de compresiones bajo estos (Figura 7). Esta situación origina un incremento del diámetro del cilindro produciendo esfuerzos de tracción perpendiculares a las líneas radiales de la probeta. Cuando el estado tensional sobrepasa la resistencia del hormigón se produce la fractura del hormigón.

Debido a la concentración de tensiones en planos concéntricos, en el momento de la rotura se producen grietas radiales perpendiculares a este campo de tensiones. Las grietas se propagan desde el centro de la probeta, específicamente desde el borde formado por el punzón de acero hacia el manto del cilindro. Una vez ocurrida la formación de la primera grieta, generalmente suelen aparecer una o dos fisuras más, como se puede ver en la Figura 8 , en la que se muestra los planos de fisuración típicos observados en los ensayos.
During the test, the load applied through the steel plates produces a conical zone of compressions under these (Figure 7). This situation originates an increase of the diameter of the cylinder producing perpendicular tensile stress to the radial lines of the specimen. When the tensional state exceeds the concrete strength the fracture of the same takes place.

Due to the stress concentration in concentric planes, at the time of the cracking, perpendicular radial cracks to this stress range take place. The cracks propagate from the center of the specimen, specifically from the edge formed by the steel punching pin towards the surface of the cylinder. 0 nce the formation of the first crack happens, usually one or two more cracks appear, as it is possible to see in Figure 8, in which the typical cracking planes observed in the tests are shown. 


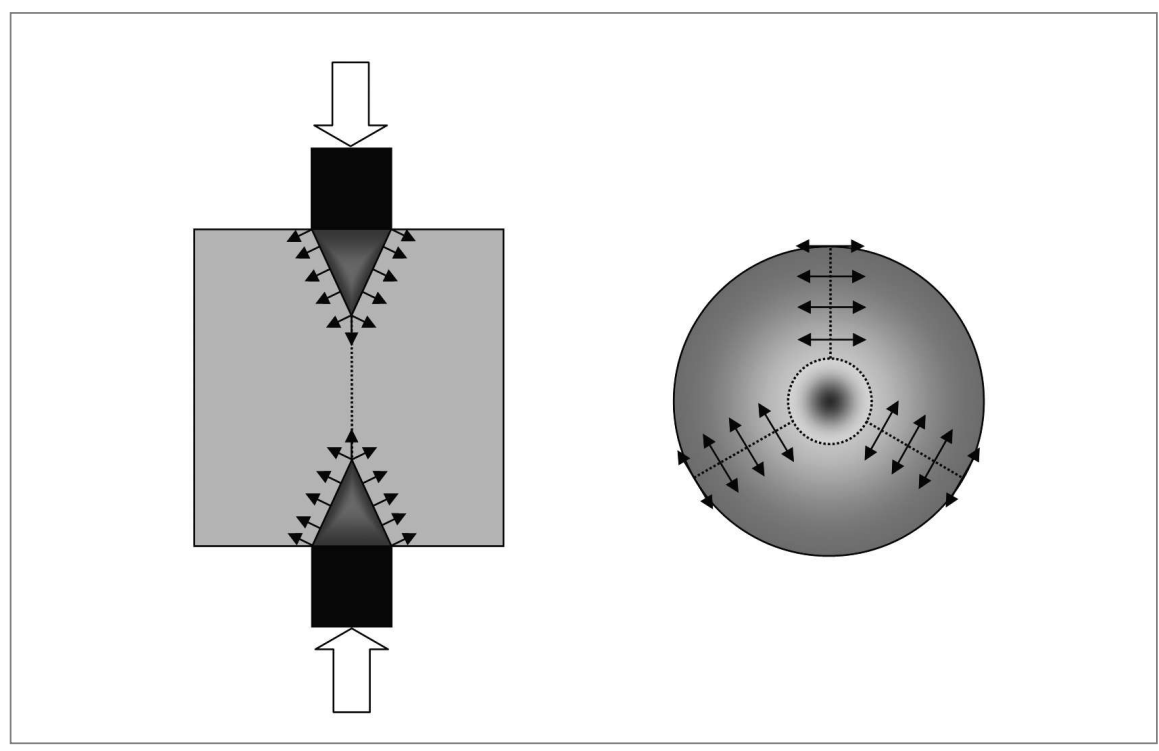

Figura 7. Cuñas de compresiones y esfuerzos de tracción desarrollados en un cilindro sometido a doble punzonamiento

Figure 7. Compressive wedges and developed tensile stress in a cylinder subjected to double punching

Diferentes estudios han propuesto ecuaciones para el cálculo de la resistencia a la tracción del hormigón $\left(f_{t}\right)$ en el ensayo de doble punzonamiento (Chen, 1970; Chen y Yuan, 1980; Bortolotti, 1988; M arti, 1989), las que, en general dependen de las dimensiones de la probeta y del ángulo de la cuña de compresiones que se forma al interior del cilindro. Basándose en un modelo elástico para la distribución de tensiones circunferenciales y verticales en el ensayo de doble punzonamiento, desarrollado por Wei y Chau (1999), Saludes el al. (2007), usando un modelo de bielas y tirantes, propusieron la relación:
Different researches have proposed equations for the calculation of the tensile strength of the concrete $\left(f_{t}\right)$ in the double punching test (Chen, 1970; Chen and Yuan, 1980; Bortolotti, 1988; Marti, 1989). Those generally depend on the dimensions of the specimen and of the angle of the compressive wedge at interior of the cylinder. Based on an elastic model for the circumferential and vertical stress distribution in the double punching test, developed by Wei and Chau (1999), Saludes et al. (2007), using a model of connecting rods and braces, proposed the relation:

$$
f_{t}=\frac{P}{9 \times \pi \times \mathrm{a} \times \mathrm{h}}
$$

Donde $P$ es la carga de rotura del material, $a$ y $h$ son la dimensiones de la probeta, definidas en la Figura 5. Esta expresión tiene la ventaja de ser la única que acepta la fractura de la probeta y, por lo tanto, permite su utilización para el cálculo de la resistencia última en cuerpos fisurados. Además, no depende del número de fisuras que se formen en el cuerpo y se puede usar para el análisis en el rango post - fisuración de los HRF (Mora, 2008).

Considerando que a través del modelo de bielas y tirantes es posible determinar la resistencia a tracción (ecuación 1) y la resistencia residual de los $\mathrm{HRF}$, parámetros fundamentales para cuantificar la contribución estructural de las fibras. Saludes at al.
Where $P$ is the critical load of the material, $a$ and $h$ the dimensions of the specimen, defined in Figure 5 . This expression has the advantage of being the only one accepting the specimen fracture and, therefore, allowing its use for the calculation of the ultimate strength in cracked bodies. In addition, it does not depend on the number of cracks that form in the body and can be used for the analysis in the post - crack rank of the FRC (M ora, 2008).

Considering that through the model of connecting rods and braces is possible to determine the tensile strength (equation 1 ) and the residual strength of the FRC, fundamental parameters to quantify the structural contribution of the fibers can be proposed. Saludes et al. 
(2007) propusieron utilizar el ensayo de doble punzonamiento para la cuantificación y control sistemático del efecto de las fibras sobre la ductilidad de los HRF, considerando que, con frecuencia, para este propósito se utiliza el ensayo a flexotracción establecido en la normativa belga NBN 15 - 238 (IBN, 1992), el que, como la propia normativa señala, no es un ensayo de control. Además, los resultados del ensayo belga presentan altas dispersiones, del orden del $20 \%$, introduciendo un factor distorsionador en el control de las obras.

En la Tabla 1 se presentan las características de los principales ensayos normalizados para determinar propiedades de los HRF. En ella se observa que la probeta especificada para el ensayo de doble punzonamiento tiene un peso considerablemente menor que la mayoría de las probetas utilizadas en los ensayos de flexotracción, con una superficie de fractura considerablemente mayor. Por otra parte, el coeficiente de variación (C.V.), se encuentra entre los más bajos.
(2007) proposed to use the double punching test for the quantification and systematic control of the fibers effect on the ductility of the FRC. For this reason the flexural test established in the Belgian standard NBN 15 - 238 (IBN, 1992) is used, the one that, as the standard indicates, is not a control test. In addition, the results of the Belgian test present high dispersions, of the order of the $20 \%$, introducing a distorting factor in the control.

In Table 1 the characteristics of the main standard tests appear to determine the FRC properties. It is observed that the weight of the specimen specified for the double punching test is considerably smaller than the majority of the specimens used in the flexural tests, with a considerable greater crack surface. On the other hand, the coefficient variation (CV.), is among the lowest ones.

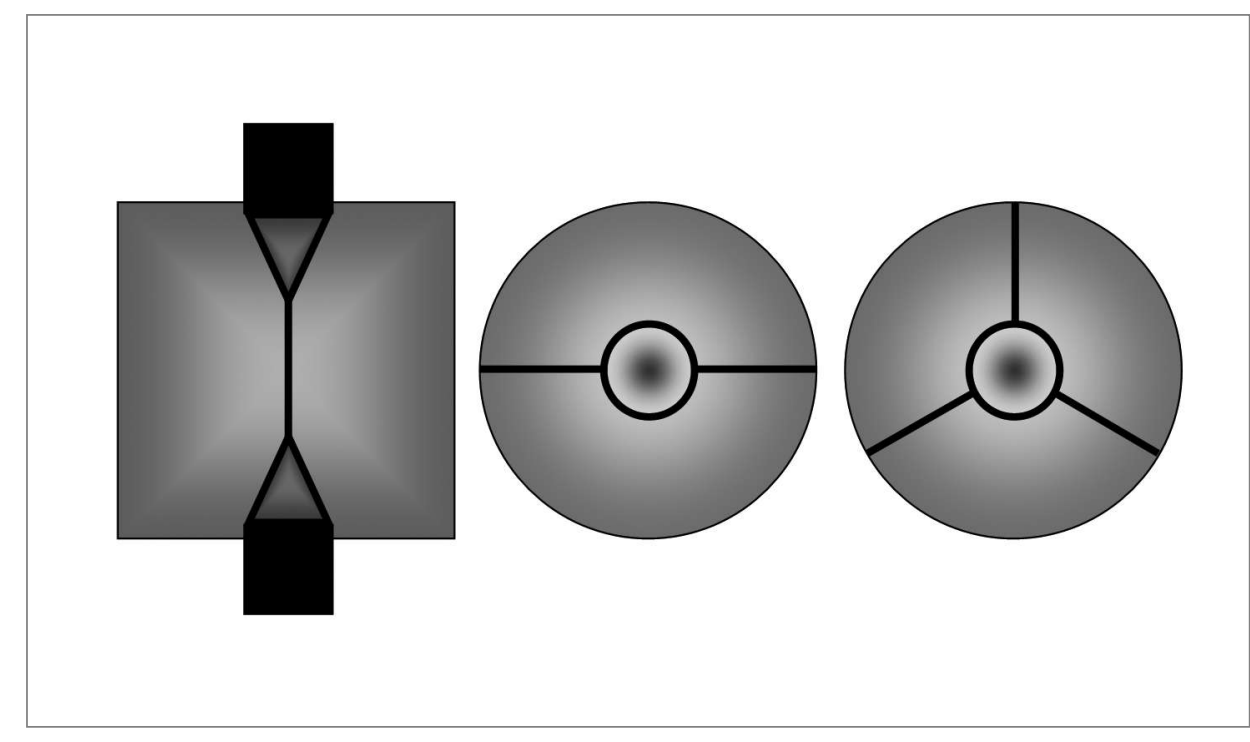

Figura 8. Planos de fisuración observados en los ensayos de doble punzonamiento Figure 8. Cracking planes observed in the double punching tests 
Tabla 1. Características de los principales ensayos utilizados para caracterizar HRF Table 1. Characteristics of the main tests used to characterize FRC

\begin{tabular}{|c|c|c|c|c|c|}
\hline Ensayo/Test & Configuración/Configuration & $\begin{array}{l}\text { Dimensiones probeta } \mathrm{mm} \times \mathrm{mm} \times \mathrm{mm} \\
\text { Specimen dimensions } \mathrm{mm} \times \mathrm{mm} \times \mathrm{mm}\end{array}$ & $\begin{array}{l}\text { Peso probeta kg } \\
\text { Specimen weight kg }\end{array}$ & $\begin{array}{l}\text { Sup. de fractura } \mathrm{m}^{2} \\
\text { Cracking surface } \mathrm{m}^{2}\end{array}$ & C.V. $(\%) / H . P .(\%)$ \\
\hline ASTM C - 1018 & 1 & $100 \times 100 \times 350$ & 8.4 & 0.01 & 15 \\
\hline NBN $15-238$ & & $150 \times 150 \times 600$ & 32.4 & 0.0255 & $12-20$ \\
\hline EFNARC - Viga/EFN ARC - Beam & & $125 \times 75 \times 550$ & 12.4 & 0.0094 & 20 \\
\hline RILEM 162 - TDF & & $125 \times 75 \times 550$ & 12.4 & 0.0094 & $10-25$ \\
\hline EN - 14651 & & $150 \times 150 \times 550$ & 29.7 & 0.0188 & $20-30$ \\
\hline Doble punzonamiento/D ouble punching & & $150 \times \phi 150$ & 6.4 & 0.0338 & 13 \\
\hline
\end{tabular}

Cabe señalar que se han recomendado ensayos de paneles, tanto cuadrados $(100 \mathrm{~mm} \times 600 \mathrm{~mm} \times 600$ $\mathrm{mm}$ ) como circulares $(75 \mathrm{~mm} \times \phi 800 \mathrm{~mm})$, sometidos a flexión con carga puntual en el centro, con los que se han alcanzado resultados con coeficientes de variación entre 6 y 13\%. No obstante, estas probetas son considerablemente grandes, con pesos cercanos a los $90 \mathrm{~kg}$, de modo que no son adecuadas para ser utilizadas en el control sistemático de los HRF en obra.

Considerando la alta variabilidad de los ensayos de flexión y sus inconvenientes experimentales, señalados detalladamente por Gopalaratnam y Gettu (1995), el ensayo de doble punzonamiento, también conocido como ensayo Barcelona (BCN), ha surgido como una alternativa bastante viable para caracterizar y controlar de modo sistemático la tenacidad de los HRF, lo que ha sido validado en extensas campañas experimentales, las que además han demostrado la gran versatilidad que presenta esta ensayo.

\section{Validación y aplicación del ensayo Barcelona}

La equivalencia entre el ensayo a flexión establecido en la NBN 15 - 238 y el ensayo BCN, se ha enfrentado en términos de la absorción de energía para los diferentes parámetros medidos: carga - deflexión y carga - deformación circunferencial a mitad de altura de la probeta, respectivamente (Molins et al., 2007).
It is highly recommended to use a precisely centered load for obtaining coefficients of variation between 6 and $13 \%$. This is valid to bending test (100 $\mathrm{mm} \times x 600 \mathrm{~mm} \times x 600 \mathrm{~mm}$ ) and compression tests (75 mm $\varnothing 00 \mathrm{~mm}$ ), . However, these specimens are considerably large, with weights near $90 \mathrm{~kg}$, so that they are not adapted to be used in the systematic control of the FRC.

Considering the high variability of the flexural tests and its experimental disadvantages, indicated in detail by Gopalaratnam and Gettu (1995), the double punching test, also known as Barcelona test (BCN), has arisen as a quite viable alternative to characterize and systematically control the FRC toughness, which has been validated in extensive experimental programs, those that in addition have demonstrated the great versatility that this test presents.

\section{Validation and application of the Barcelona test}

Equivalence between the established flexural test to NBN 15 - 238 and BCN test, has been confronted in terms of the energy absorption for the different measured parameters: load - deflection and load - circumferential deformation in the middle of the height of the specimen, respectively (Molins et al., 2007). 
Para obtener la relación, es necesario definir el desplazamiento de apertura circunferencial total (TCOD por el inglés Total Circumferential O pening Displacement), medido como una apertura circunferencial $(\Delta \Phi)$ para el ensayo BCN y la deflexión vertical $(\delta)$ para el ensayo de flexión, el que proporciona la misma apertura promedio de fisura ( $w$ ) en ambos ensayos.

Suponiendo que después del agrietamiento en el ensayo de flexión se desarrolla sólo una fisura cercana al centro de la luz y su altura es casi la altura de la viga, de este modo, las dos mitades rotan como cuerpos rígidos en torno a una rótula (Figura 9), es posible obtener a relación geométrica entre la deflexión vertical y el ancho de la fisura:
In order to obtain the relation, it is necessary to define the total circumferential opening displacement (TCO D) measured as a circumferential opening $(\Delta \Phi)$ for the BCN test and the vertical deflection $(\delta)$ for the flexural test, the one that provides same average opening of the crack $(w)$ in both tests.

Assuming that after the crack in the flexural test only one crack develops near the midspan and its height is almost the height of the beam, thus, two halves rotate like rigid bodies around a support (Figure 9), is possible to obtain the geometric relation between the vertical deflection and the width of the crack: donde $h$ es la altura de la probeta prismática, $l$ la mitad de la luz, $\delta$ la deflexión vertical, $\theta$ la rotación en los apoyos, $w$ la apertura de desplazamiento de punta de la fisura y $w_{N B N}$ la apertura media de la fisura, considerando la superficie de fractura completa. Tomado las proporciones geométricas y el tamaño real de la probeta en el ensayo de flexión belga, la ecuación (2) se puede reescribir como:

$$
\theta=\frac{\delta}{l} \rightarrow \theta=\frac{w / 2}{h}=\frac{w_{N B N}}{h}
$$

$$
w_{N B N}=\frac{w}{2}=\frac{2}{3} \delta
$$

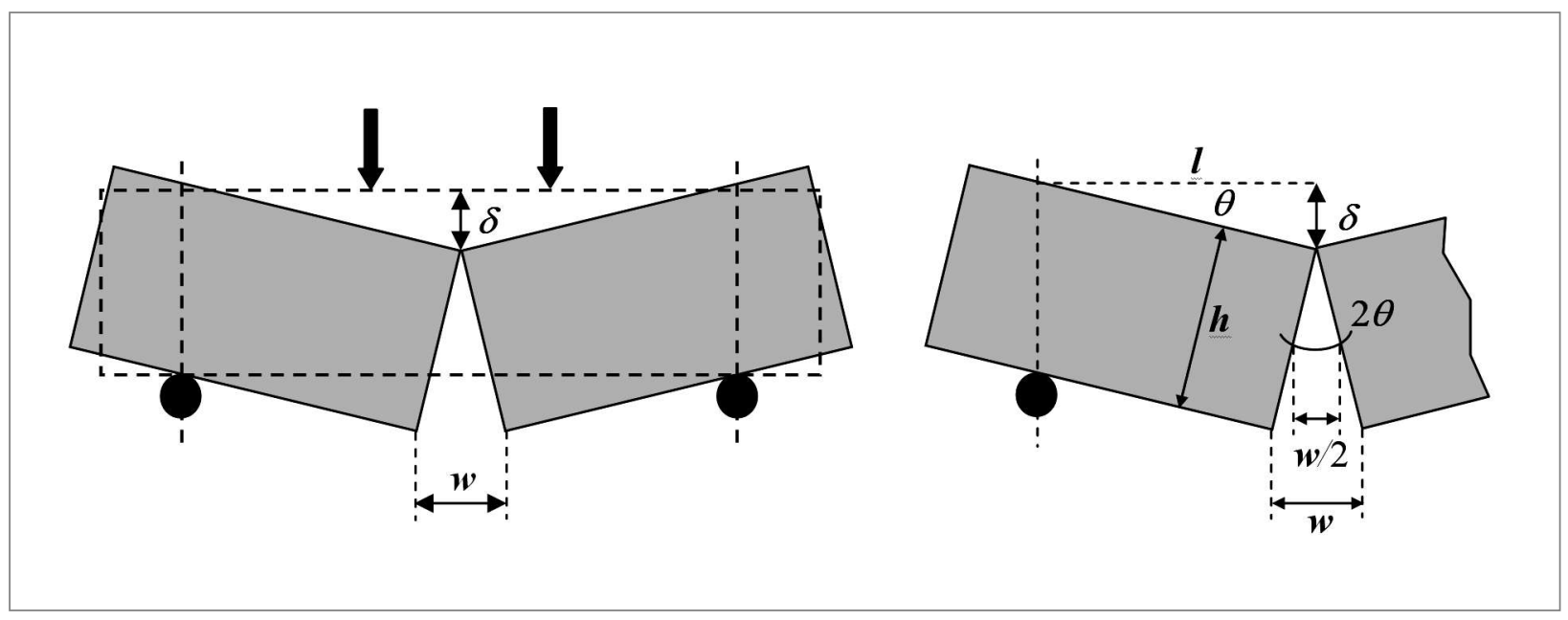

where " $h$ " is the height of the prismatic specimen, "I" is half of the span, $\delta$ the vertical deflection, $\theta$ the rotation in the supports, $w$ the opening displacement of the end of the crack and $w_{N B N}$ the average opening of the crack, considering the surface of the complete crack. Taken the geometric proportions and the specimens real size in the Belgian flexural test, the equation (2) can be rew ritten like this:

Figura 9. Movimiento ideal supuesto para el ensayo de flexión después del agrietamiento y parámetros geométricos involucrados Figure 9. Ideal movement assumption for the flexural test after the cracking and geometric parameters involved. 
Una relación similar entre $\operatorname{TCOD}(\Delta \Phi)$ y la apertura media de la fisura se puede establecer para el ensayo BCN. Se considera que la probeta falla con tres fisuras radiales de ancho similar. Normalmente, los ensayos muestras tres grietas radiales, pero ellas no suelen ser del mismo ancho. Sin embargo, este último supuesto ayuda a correlacionar los resultados de ambos ensayos. De acuerdo al supuesto considerado, la relación entre la apertura promedio de la fisura y el TCOD es:
A similar relation between $\operatorname{TCOD}(\Delta \Phi)$ and the average opening of the crack can be established for BCN test. It is considered that the specimen fails with three radial cracks of similar width. N ormally, the tests display three radial cracks, but they usually are not of the same width. N evertheless, this last assumption helps to correlate the results of both tests. According to the considered assumption, the relation between the average opening of the crack and the TCOD are:

$$
\Delta \Phi=3 w_{B C N}
$$

donde $\triangle \Phi$ es el TCOD y $w_{B C N}$ el ancho medio de las fisuras radiales.

Imponiendo la condición de que el ancho medio de las fisuras en ambos ensayos debe ser igual, se tiene: where $\triangle \Phi$ is the TCOD and $w_{B C N}$ the average width of the radial cracks.

Imposing the condition that the average width of the cracks in both tests must be equal, we have:

$$
w_{B C N}=\frac{\Delta \Phi}{3}=w_{N B N}=\frac{2}{3} \delta
$$

Para validar el ensayo Barcelona, en la Universidad Politécnica de Cataluña en Barcelona, se han planteado y desarrollado una serie de campañas experimentales (Aguado et al., 2005). A partir de los resultados alcanzados se han fijado los parámetros geométricos y las condiciones de carga que definen y caracterizan el ensayo.

Saludes et al. (2007) desarrollaron una amplia campaña experimental utilizando muestras de hormigón reforzado con fibras obtenidas en las obras de construcción de dos estaciones de la Línea 9 del Metro de la ciudad de Barcelona. Esta campaña consideró el estudio de diferentes parámetros que influyen en los resultados del ensayo, incluyendo el tipo y contenido de fibras, esbeltez y altura de la probeta, tamaño del cuño de carga y la velocidad de carga. Con los resultados de cada ensayo, se calculó la energía disipada por las probetas durante el proceso de rotura y el correspondiente coeficiente de variación (C.V.) de los resultados, los que se presentan en la Tabla 2.
In order to validate the Barcelona test, in the Polytechnical University of Catalonia in Barcelona, they have considered and developed a series of experimental programs (Aguado et al., 2005). From the results obtained the geometric parameters and the conditions of load that define and characterize the test have been established.

Saludes et al. (2007) developed an ample experimental program using FRC obtained in construction sites of two stations of Line 9 of the Subway of the city of Barcelona. This program considered the study of different parameters that influence in the results of the test, including the type and content of fibers, slenderness and height of the specimen, size of the load application plate and the speed of load. With the results of each test, the energy dissipated by the specimens during the process of failure was calculated and the corresponding coefficient of variation (C.V.) of the results, those shown in Table 2. 
Tabla 2. Coeficientes de variación máximos obtenidos por Saludes (2006).

\begin{tabular}{|c|c|c|}
\hline $\begin{array}{l}\text { Parámetro } \\
\text { Parameter }\end{array}$ & $\begin{array}{l}\text { Valores de referencia } \\
\text { Reference Values }\end{array}$ & $\begin{array}{l}\text { C.V. } \\
(\%)\end{array}$ \\
\hline \multirow{2}{*}{$\begin{array}{l}\text { Esbeltez y altura de la probeta }(h) \\
\text { Slenderness and height of the specimen (h) }\end{array}$} & $\mathrm{h}=150 \mathrm{~mm}$ & 12 \\
\hline & $\mathrm{h}=300 \mathrm{~mm}$ & 15 \\
\hline \multirow{2}{*}{$\begin{array}{l}\text { Diámetro de plato de carga (a) } \\
\text { Load plate diameter (a) }\end{array}$} & $\mathrm{a}=38 \mathrm{~mm}(\mathrm{~d} / 4)$ & 15 \\
\hline & $a=50 \mathrm{~mm}(d / 3)$ & 36 \\
\hline \multirow{3}{*}{$\begin{array}{l}\text { Velocidad de desplazamiento del pistón de carga } \\
\text { Speed displacement of the loading piston }\end{array}$} & $0,25 \mathrm{~mm} / \mathrm{min}$ & 12 \\
\hline & $0,50 \mathrm{~mm} / \mathrm{min}$ & 11 \\
\hline & $0,75 \mathrm{~mm} / \mathrm{min}$ & 44 \\
\hline
\end{tabular}

Los valores del C.V. de la Tabla 2 corresponden a los máximos obtenidos en las diferentes series de ensayos. Considerando esos resultados, se han establecido las siguientes condiciones generales para le ejecución del ensayo:

- Diámetro de la probeta $(d): 150 \mathrm{~mm}$.

- Altura de la probeta (h): $150 \mathrm{~mm}$.

- Diámetro del disco de carga (a): 38 mm (equivalente a $d / 4$ ).

- Velocidad de desplazamiento del actuador: 0,5 $\mathrm{mm} / \mathrm{min}$.

- Control del ensayo a través de la deformación circunferencial del cilindro.

Estas condiciones fueron especificadas en la norma UNE 83 - 515, Hormigones con fibras Determinación de la resistencia a fisuración, tenacidad y resistencia residual a tracción, recientemente aprobada por AEN O R (2008).

Para contrastar el ensayo Barcelona con el procedimiento establecido en la norma belga NBN B 15 - 238, Saludes et al. (2007) realizaron ensayos utilizando muestras de hormigón reforzados con distintos contenidos de fibras de plástico $\left(5 \mathrm{~kg} / \mathrm{m}^{3}\right.$ y $\left.6,5 \mathrm{~kg} / \mathrm{m}^{3}\right)$ y de acero $\left(25 \mathrm{~kg} / \mathrm{m}^{3}\right)$, obtenidas en la construcción de la estación Bon Pastor del Metro de Barcelona. De los resultados alcanzados (mostrados en la Tabla 3), se concluye que las dispersiones medias (coeficientes de variabilidad respecto los valores individuales obtenidos para cada probeta) que se obtienen con los resultados derivados del ensayo Barcelona son bajas, en comparación con las obtenidas en el ensayo a flexotracción basado en la norma N BN B 15-238. Para probetas ensayadas a 28
The C.V. values shown in Table 2 correspond to the maximums obtained in the different series of tests. Considering those results, the following general conditions have been settled for the execution of the test:

- Specimen diameter (d): $150 \mathrm{~mm}$.

- Specimen height (h): $150 \mathrm{~mm}$.

- Diameter of the loading disk (a): $38 \mathrm{~mm}$ (equivalent to $d / 4$ ).

- Speed displacement of the piston: $0.5 \mathrm{~mm} / \mathrm{min}$.

- Test control through the circumferential deformation of the cylinder

These conditions were specified in the UNE 83 - 515 standard, Concrete with fiber - Determination of the strength in face of a crack, toughness and residual tensile strength, recently approved by AEN O R (2008).

In order to compare the Barcelona test with the procedure established in the Belgian NBN B 15 - 238 standard, Saludes et al. (2007) performed tests using samples of reinforced concrete with different contents of plastic fibers $\left(5 \mathrm{~kg} / \mathrm{m}^{3}\right.$ and 6.5 $\left.\mathrm{kg} / \mathrm{m}^{3}\right)$ and steel $\left(25 \mathrm{~kg} / \mathrm{m}^{3}\right)$, obtained in the construction of the Bon Pastor station of the Barcelona Subway. From the results obtained (shown in Table 3), it can be concluded that the average dispersions (coefficients of variability respect the individual values obtained for each specimen) that are obtained with the results derived from the Barcelona test are low, in comparison with the ones obtained in the flexural test based on the NBN B 15-238 standard. For specimens tested at 28 days of 
días se obtiene una dispersión media del 7,7\% para la carga máxima, del 15,1\% respecto la absorción de energía para una carrera de $3 \mathrm{~mm}$ medida desde el origen y del $17,3 \%$ para la tenacidad medida para una apertura circunferencial de $3 \mathrm{~mm}$. Además, para los casos estudiados, se ha establecido una buena equivalencia entre ambos ensayos (Figura 10), de modo que, los valores de la tenacidad determinada usando el ensayo Barcelona $\left(E_{B C N}\right)$ y la energía obtenida con el ensayo de la viga $\left(E_{N B N}\right)$, se pueden calcular usando la ecuación (Molins et al., 2008b): age an average dispersion of $7.7 \%$ for the fully factored load is obtained; that is, $15.1 \%$ respect to the energy absorption for an opening of $3 \mathrm{~mm}$ measured from the origin and $17.3 \%$ for the toughness measured for a circumferential opening of $3 \mathrm{~mm}$. In addition, for the researched cases, a good equivalence between both tests has been established (Figure 10), so that, the values of a given toughness using the Barcelona test $\left(E_{B C N}\right)$ and the energy obtained with the beam test $\left(E_{N B N}\right)$, can be calculated using the equation (Molins et al., 2008b):

$$
E_{N B N}=0,302 \times E_{B C N}-20,537(\mathrm{~N} \times \mathrm{mm})(6)
$$

Tabla 3. Resultados de Saludes et al. (2007), a los 28 días, en $\mathrm{N} \times \mathrm{mm}$ Table 3. Results of Saludes et al. (2007), to 28 days, in $\mathrm{N} \times \mathrm{mm}$

\begin{tabular}{|c|c|c|c|c|c|c|c|c|c|c|}
\hline & \multirow[b]{2}{*}{$\begin{array}{l}\text { Carga máxima (kN) } \\
\text { Maximum load }(\mathrm{kN})\end{array}$} & \multicolumn{4}{|c|}{ Barcelona: TCOD $(\mathrm{mm})$} & \multirow[b]{2}{*}{$\begin{array}{l}\text { Carga máxima (kN) } \\
\text { Maximum load (kN) }\end{array}$} & \multicolumn{4}{|c|}{ NBN B 15-238: $\boldsymbol{d}(\mathrm{mm})$} \\
\hline & & 1 & 2 & 3 & 4 & & 0,5 & 1,0 & 1,5 & 2,0 \\
\hline BK 5 & $\begin{array}{c}192.0 \\
(9,7 \%)\end{array}$ & $\begin{array}{c}114,7 \\
(21.6 \%)\end{array}$ & $\begin{array}{c}167,2 \\
(21.0 \%)\end{array}$ & $\begin{array}{c}202,0 \\
(16.0 \%)\end{array}$ & $\begin{array}{c}230,0 \\
(13.6 \%)\end{array}$ & $\begin{array}{c}35.39 \\
(10,7 \%)\end{array}$ & $\begin{array}{c}18,3 \\
(17,8 \%)\end{array}$ & $\begin{array}{c}31,6 \\
(16,6 \%)\end{array}$ & $\begin{array}{c}43,2 \\
(17,9 \%)\end{array}$ & $\begin{array}{c}55,0 \\
(20,9 \%)\end{array}$ \\
\hline BK 6,5 & $\begin{array}{c}183.0 \\
(7,2 \%)\end{array}$ & $\begin{array}{c}113,2 \\
(23.1 \%)\end{array}$ & $\begin{array}{c}167,5 \\
(25.9 \%)\end{array}$ & $\begin{array}{c}203,8 \\
(23.6 \%)\end{array}$ & $\begin{array}{c}233,8 \\
(22.5 \%)\end{array}$ & $\begin{array}{c}35.67 \\
(6,0 \%)\end{array}$ & $\begin{array}{c}13,68 \\
(10,1 \%)\end{array}$ & $\begin{array}{c}22,98 \\
(16,9 \%)\end{array}$ & $\begin{array}{c}35,22 \\
(9,7 \%)\end{array}$ & $\begin{array}{c}46,79 \\
(11,4 \%)\end{array}$ \\
\hline W 25 & $\begin{array}{l}191.0 \\
(6,2 \%)\end{array}$ & $\begin{array}{c}116,3 \\
(11.1 \%)\end{array}$ & $\begin{array}{c}173,3 \\
(11.5 \%)\end{array}$ & $\begin{array}{c}209,8 \\
(12.2 \%)\end{array}$ & $\begin{array}{c}236,0 \\
(13.1 \%)\end{array}$ & $\begin{array}{c}44.16 \\
(20,8 \%)\end{array}$ & $\begin{array}{c}18,32 \\
(25,9 \%)\end{array}$ & $\begin{array}{c}31,57 \\
(26,8 \%)\end{array}$ & $\begin{array}{c}43,23 \\
(24,7 \%)\end{array}$ & $\begin{array}{c}55,03 \\
(24,6 \%)\end{array}$ \\
\hline
\end{tabular}

Coeficiente de variación entre paréntesis/Coefficient Variation in parenthesis

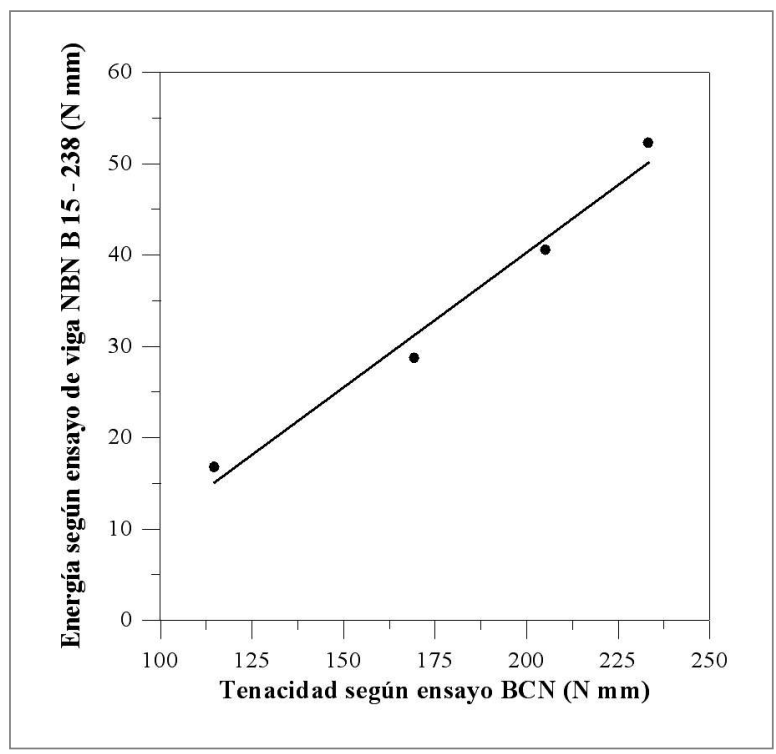

Figura 10. Regresión lineal entre $E_{B C N}$ y $E_{N B N}$ obtenida con los resultados de Saludes et al. (2007) Figure 10. Linear regression between $E_{B C N}$ y $E_{N B N}$ from the results obtained from Saludes et al. (2007) 
Guardia y Molins (2008) realizaron la caracterización y control de diferentes hormigones de alta trabajabilidad, con y sin fibra, de resistencia convencional y de alta resistencia utilizando el ensayo $\mathrm{BCN}$, contrastando los resultados obtenidos con la caracterización por medio del ensayo establecido en la recomendación EN 14561:2005 (CEN, 2005).

A partir de la comparación entre los ensayos BCN y EN 14561:2005, se ha obtenido una correlación entre los resultados de la resistencia residual a tracción del ensayo Barcelona con la resistencia residual calculada a partir de los resultados de los ensayos de flexotracción. Dicha correlación consiste en aplicar un factor de 1.5 a la resistencia residual obtenida mediante el ensayo Barcelona para una elongación circunferencial de valor $2.5 \mathrm{~mm}$ y es aplicada con éxito a otros HRF, demostrando la aplicabilidad del ensayo Barcelona al control de calidad del HRF en aplicaciones estructurales. Asimismo, esa correlación puede ser empleada para determinar el contenido óptimo de fibras correspondiente a una prestación exigida al hormigón, sin tener que recurrir a los laboriosos ensayos de vigas a flexión. Además, los resultados de Guardia y Molins (2008) muestran que el ensayo Barcelona permite evaluar la resistencia a tracción del hormigón sin necesidad de recurrir a ensayos complementarios.

Sin embargo, los resultados obtenidos en la campaña experimental realizada por Guardia y Molins (2008) no han sido satisfactorios para todas las cuantías de fibras de acero, debido a que, a diferencia del ensayo de flexión, no se observaron diferencias significativas entre los resultados alcanzados con hormigones reforzados con cuantías de fibras de 40 y $60 \mathrm{~kg} / \mathrm{m}^{3}$. De la observación de las probetas, se concluyó que este hecho se debió a una orientación en planos verticales de las fibras que se produjo durante el vertido, lo que debilitaba la resistencia post - fisuración en dichos planos.

Mora (2008) realizó otra extensa campaña experimental que ha permitido validar el uso del ensayo Barcelona sobre testigos de hormigón endurecido. En estos ensayos se utilizaron testigos de diferentes diámetros ( $\phi=75 \mathrm{~mm}, 100 \mathrm{~mm}$ y $150 \mathrm{~mm}$ ) extraídos de dovelas utilizadas en la construcción del tramo Can Zam de la Línea 9 del Metro de Barcelona, las que estaban reforzadas con $60 \mathrm{~kg} / \mathrm{m}^{3}$ de fibra de acero con extremos conformados.

De esos ensayos se concluyó que los resultados obtenidos en las probetas $\phi 100 \mathrm{~mm}$ son muy similares a los alcanzados en las probetas $\phi 150 \mathrm{~mm}$. Sin embargo, para el caso de las probetas de $\$ 75 \mathrm{~mm}$ se obtiene resultados de resistencias a tracción indirecta con variación más alta en cargas residuales y sus tenacidades asociadas,
Guardia and Molins (2008) performed the characterization of different high workability concretes, with and without fiber, of conventional and high strength using the BCN test, contrasting the results obtained with the characterization by means of the test established in the EN 14561:2005 (CEN, 2005) recommendation.

When comparing the BCN and EN 14561:2005 tests, a correlation has been obtained between the results of the residual strength of the Barcelona test and the residual strength calculated from the results of the flexural tests. This correlation consists of applying a factor of 1.5 to the residual strength obtained by means of the Barcelona test for a circumferential elongation of $2.5 \mathrm{~mm}$ value and is successfully applied to other FRC, demonstrating the applicability of the Barcelona test to the quality control of the FRC in structural applications. Also, that correlation can be used to determine the optimal fiber content corresponding to a benefit demanded from the concrete, without having to perform laborious tests of flexural beams. In addition, the results of Guardia and Molins (2008) show that the Barcelona test allows to evaluate the flexural strength of the concrete without need of performing complementary tests.

$\mathrm{N}$ evertheless, the results obtained in the experimental program realized by Guardia and Molins (2008) have not been satisfactory for all the amounts of steel fibers, because, unlike the flexural test, significant differences between the results accomplished with reinforced concretes with amounts of 40 and $60 \mathrm{~kg} / \mathrm{m}^{3}$ were not observed. From the specimens observation, it can be concluded that this fact was due to a direction in vertical planes of the fibers that took place during the split, which lowered the post - crack strength in these planes.

Mora (2008) performed another extensive experimental program that has allowed validating the use of the Barcelona test on hard concrete. In these tests specimens of different diameters $(\phi=75 \mathrm{~mm}, 100 \mathrm{~mm}$ and $150 \mathrm{~mm}$ ) extracted from voussoirs used in the construction of the Can Zam section of Line 9 of the Barcelona Subway were used, those that were reinforced with $60 \mathrm{~kg} / \mathrm{m}^{3}$ of steel fiber with shaped ends.

From those tests it was concluded that the results obtained in the $\phi 100 \mathrm{~mm}$ specimens are very similar to those obtained in the $\phi 150 \mathrm{~mm}$ specimens. N evertheless, in the case of the $\phi 75 \mathrm{~mm}$ specimens results of indirect tensile strength with higher variation in residual and their associated toughness are obtained, 
respecto a las probetas $\phi 150 \mathrm{~mm}$, que la obtenida en las probetas $\phi 100 \mathrm{~mm}$. O bservándose que los resultados del ensayo de doble punzonamiento también entregan resultados satisfactorios de resistencia a tracción en los tres diámetros estudiados, con bajas dispersiones entre probetas de la misma zona, y entre probetas de diferentes zonas y diferentes dovelas.

Los resultados de carga y tenacidad para probetas de $\phi 150 \mathrm{~mm}$, permiten concluir que la dispersión de resultados, con C.V. entre 18 y $27 \%$ para cargas, y de 9 a $17 \%$ para tenacidades, es de un orden de magnitud inferior, y en el peor de los casos similar al obtenido en otros ensayos (sobre el 30\% para el cálculo de cargas y tenacidades) utilizados para caracterizar la resistencia a tracción del hormigón y sus tenacidades asociadas.

Zepeda (2008), desarrolló en Chile una campaña experimental siguiendo las recomendaciones de Saludes et al. (2007), pero usando un sistema de ensayos convencional, con control de desplazamiento del actuador. Este planteamiento abre las puertas a un uso generalizado de este tipo de ensayo ya que no requiere de equipamiento adicional al que ya se dispone usualmente en todos los laboratorios.

Esta campaña incluyó hormigones de resistencia normal ( $f_{c}=30 \mathrm{MPa}$ a los 28 días), reforzados con diferentes cuantías de fibras de acero (40 y $\left.80 \mathrm{~kg} / \mathrm{m}^{3}\right)$. Durante los ensayos se obtuvo las curvas carga desplazamiento relativo de las placas de carga, la que se utilizó para determinar la tenacidad absoluta y los índices de tenacidad en forma satisfactoria. Adicionalmente, en su trabajo Zepeda comparó los valores de la resistencia a la tracción determinada en forma indirecta mediante el ensayo brasileño $\left(f_{B R A}\right)$ y Barcelona $\left(f_{B C N}\right)$, obteniendo, como se puede ver en la Tabla 4, coeficientes de variación significativamente menores con este último ensayo. with respect to the $\phi 150 \mathrm{~mm}$ and $\phi 100 \mathrm{~mm}$ specimens. It is observed that the results of the double punching test also give satisfactory results of tensile strength in the three studied diameters, with low dispersions between specimens of the same zone, and between specimens of different zones and different voussoirs.

The results of load and toughness for the $\phi 150$ $\mathrm{mm}$ specimens, allow to conclude that the dispersion of results, with coefficient variation between 18 and $27 \%$ per loads, and from 9 to $17 \%$ for toughness, is in the order of an inferior magnitude, and in the worse of cases, similar to the one obtained in other tests (over 30\% for the calculation of loads and toughness) used to characterize the tensile strength of the concrete and its associate toughness.

Zepeda (2008), developed in Chile an experimental program following the recommendations given by Saludes et al. (2007), but using a conventional test system, with a piston displacement control. This statement opens the door to a generalized use of this type of test since it doesn't require of additional equipment other than the one found in all laboratories.

This program included normal strength concretes (fc $=30 \mathrm{MPa}$ at 28 days), reinforced with different quantities of steel fibers $\left(40\right.$ y $\left.80 \mathrm{~kg} / \mathrm{m}^{3}\right)$. D uring the test the loads - relative displacement curves of the load plates was obtained, used to determine the absolute toughness and the toughness indexes in a satisfactory way. In addition, in his work Zepeda compared the values of the tensile strength indirectly determined by mean of the Brazilian $\left(f_{B R A}\right)$ and Barcelona $\left(f_{B C N}\right)$ test, obtaining with the latter, as it can be seen in Table 4, significantly lower coefficient variations.

Tabla 4. Coeficientes de variación de hormigones con diferentes contenidos de fibras Table 4. Coefficient variation of concrete with different fiber contents

\begin{tabular}{|l|c|c||}
\hline \multirow{2}{*}{$\begin{array}{l}\text { Contenido de fibras, } \mathrm{kg} / \mathrm{m}^{3} \\
\text { Fiber contents, } \mathrm{kg} / \mathrm{m}^{3}\end{array}$} & \multicolumn{2}{|c|}{ C.V.\% } \\
\cline { 2 - 3 } & $f_{B R A}$ & $f_{B C N}$ \\
\hline 0 & 9,71 & 5,00 \\
\hline 40 & 2,58 & 3,71 \\
\hline 80 & 8,96 & 2,29 \\
\hline
\end{tabular}


Finalmente, García (2006) concluyó que, a las ventajas operacionales que presentan el ensayo de doble punzonamiento, se debe sumar un menor costo, con un ahorro del orden del $64 \%$ frente al uso del ensayo de flexión según la norma belga NBN B 15238.

\section{Conclusiones}

Existen diferentes normas y recomendaciones internacionales que permiten cuantificar la tenacidad de los HRF, basadas, principalmente, en el ensayo de flexotracción. Sin embargo, los procedimientos experimentales y las metodologías de análisis presentan una serie de inconvenientes que han sido previamente discutidos. Además, los resultados alcanzados a través de ellos presentan una alta variabilidad.

El ensayo de tracción indirecta o ensayo brasileño ha demostrado ser poco apropiado para el control sistemático de los HRF, debido a que el estado tensional que se genera no permite que toda la energía al macenada en la probeta se disipe a través de la zona fisurada, además, presenta una serie de inconvenientes y dificultades experimentales.

El ensayo de doble punzonamiento o ensayo Barcelona ha demostrado ser adecuado para el control sistemático de HRF en obra, debido a que requiere de una probeta de pequeñas dimensiones, que se pueden obtener mediante probetas moldeadas o a través de testigos de hormigón endurecido. Además tiene la ventaja de que presenta una su superficie específica de fractura significativamente mayor que las vigas utilizadas en los ensayos de flexotracción establecido en otras recomendaciones.

Los resultados de diferentes campañas experimentales, realizadas utilizando tanto probetas moldeadas como testigos de hormigón endurecido, permiten establecer un coeficiente de variación medio del $13 \%$, ubicando al ensayo Barcelona entre los que presentan menor variabilidad para el control sistemático de los HRF. Al mismo tiempo, usando este ensayo se puede determinar la resistencia a tracción indirecta con variabilidades menores que el ensayo brasileño.

Su procedimiento ha sido recientemente normalizado por AENOR (UNE 83515) en España, estableciéndose las condiciones que permitirán realizar ensayos comparativos entre laboratorios.
Finally, García (2006) concluded that, to the operational advantages that the double punching test presents, a lower cost should be added, with savings in the order of $64 \%$ when compared to the use of the bending test according to the Belgium NBN B 15-238 standard.

\section{Conclusions}

There are different standards and international recommendations that allow quantifying the FRC toughness, based, mainly, in the flexural test. N evertheless, the experimental procedures and methodologies of analysis present a series of disadvantages that have been previously discussed. In addition, the results reached through them present a high variability.

The flexural test or Brazilian test has proven to be less appropriate for the systematic control of FRC, because the tensile state generated does not allow that all the energy contained in the specimens to dissipate through the cracked zone, in addition it presents other disadvantages and experimental difficulties.

The double punching test or Barcelona test has demonstrated to be adapted for the systematic control of $F R C$, because it requires a small specimen, that can be obtained by means of molded specimens or through concrete cores. In addition it has the advantage of which it presents a specific surface of fracture significantly greater than the beams used in the flexural tests established in other recommendations.

The results of different experimental programs, carried out using both molded specimens cores, allow establishing an average coefficient variation of $13 \%$, locating the Barcelona test among the ones that present minor variability for the systematic control of FRC. At the same time, using this test the indirect tensile strength with lower variability than the Brazilian test can be determined.

Its procedure has been recently standardized by AEN OR (UNE 83515) in Spain, setting the conditions that will allow the performance of comparative tests between laboratories. 
Por último, cabe reseñar que es necesario desarrollar campañas experimentales que permitan ampliar su aplicabilidad, por ejemplo, utilizando diferentes sistemas de control y relacionando diferentes parámetros experimentales que pueden tener efecto sobre las mediciones y resultados alcanzados.

\section{Agradecimientos}

La estadía del primer autor en Barcelona durante la elaboración de este artículo fue financiada parcialmente por el Departamento de O bras Civiles de la Universidad Técnica Federico Santa María de Valparaíso, Chile, y el Departamento de Ingeniería de la Construcción de la Universidad Politécnica de Cataluña de Barcelona, España. Los ensayos realizados en Chile fueron financiados por la compañía Cementos Polpaico S.A. (Grupo Holcim).
Finally, it is possible to indicate that it is necessary to develop experimental programs that allow extending its applicability, for example, using different control systems and relating different experimental parameters that can have effect on the measurements and results reached.

\section{Acknowledgments}

The stay of the first author in Barcelona during the elaboration of this study was partially financed by the Civil Engineering Department of the Universidad Federico Santa M aria of Valparaiso, Chile, and the Department of Engineering of the Construction of the Polytechnical University of Catalonia of Barcelona, Spain. The tests realized in Chile were financed by Cemento Polpaico S.A. (Holcim Group).

\section{Referencias / References}

$\mathrm{ACl}$ (2008), M easurement of Properties of Fiber Reinforced Concrete, Reported by ACI Committee 544, ACI 544.2R89 (Reaproved 1999), ACI M anual of Concrete Practice, Part 6, 11 pp.

Aenor (1985), UNE 83 - 306 Resistencia a Tracción Indirecta (Ensayo Brasileño), Madrid, España. 4 pp. Aenor (2004), UNE 83 - 508 Hormigones con Fibras. Determinación del Índice de Tenacidad a Compresión, Madrid, España, $6 \mathrm{pp}$.

Aenor (2004), UNE 83 - 510 Hormigones con fibras. Determinación del índice de tenacidad y resistencia a primera fisura, Madrid, España, 6 pp.

Aenor (2008), U NE 83 - 515 Hormigones con fibras. Determinación de la resistencia a fisuración, tenacidad y resistencia residual a tracción. Ensayo Barcelona, Madrid, España, 7 pp.

Aguado A., Mari A y Molins C. (2005), Estudio de viabilidad del ensayo Barcelona. III Congreso de ACHE de Puentes y Estructuras. Zaragoza 14 - 17 de noviembre de 2005. Vol. 1. Gestión de Estructuras, pp 275 - 288.

ASTM International (2002), C 1018 - 97, Standard Test M ethod for Flexural Toughness and First-Crack Strength of Fiber-Reinforced Concrete (U sing Beam W ith Third-Point Loading), ASTM Annual Book of Standards, Vol 04.02, Philadelphia, U SA, pp 546 553.

ASTM International (2002), C 496 - 96, Standard Test M ethod for Splitting Tensile Strength of Cylindrical Concrete Specimens, ASTM Annual Book of Standards, Vol 04.02, Philadelphia, USA, pp 281 - 287.

Bernard E. S. (1999), Correlations in the Performance of Fibre Reinforced Shotcrete Beams and Panels. Engineering Report CE9, School of Civic Engineering and Environment, University of Western Sydney, Nepean, Australia. Brühwiler E. y Wittmann F.H. (2003), The Wedge Splitting Test. A N ew M ethod of Performing Stable Fracture Mechanics Test". Eng. Fracture Mechanical. Vol.35. pp 117 - 125.

Bortolotti L. (1988), Double Punch Test for Tensile and Compressive Strengths in Concrete. ACI M aterials Journal. Vol. 85, pp $26-32$.

Carmona S., Gettu R. y Aguado A. (1998), Study of the post-peak behavior of Concrete in the Splitting-Tension Test, FRAM COS - 3, Fracture Mechanics of Concrete Structures, Gifu (Japón) 12 - 16 de octubre de 1998. Eds. H. Mihashi y K. Rokugo, AEDIFICATIO Publishers, Feiburg, Alemania, Vol. 1, pp 111 - 120.

CEN (2005), EN 14651: Test method for metallic fibered concrete - M easuring the flexural tensile strength (limit of proportionality (LO P), residual). European Committee for Standaritzation, Bruselas, Bélgica. 20 pp. 
Chen W. F. (1970), Double Punch Test for Tensile Strength of Concrete, ACl Materials Journal, Vol. 67 (2), pp 993 - 995.

Chen W. F. y Yuan R. L. (1980), Tensile Strength of Concrete: Double-Punch Test. Journal of the Structural Division, ASCE, Vol. 106, pp 1673 - 1693.

Cho B. El - Shakra Z. y Gopalaratnam V.S. (1992), Failure of FRC in Direct and Indirect Tensile Test Configuration, Proceedings of International Symposium on Fatigue and Fracture Steel and Concrete Structures, O xford \& IBH Publ., N ew D elhi, India, pp $587-601$.

CEN (2005), EN 14651: Test M ethod for Metallic Fibered Concrete - Measuring the Flexural Tensile Strength (limit of proportionality (LOP), residual). European committee for standaritzation, Bruselas, Bélgica.

Flores B. (2005), Propiedades del Hormigón Reforzado con Fibras de Acero Sometido a Compresión. Memoria para optar al título de Constructor Civil, U niversidad Técnica Federico Santa M aría, Val paraíso, Chile, 96 pp.

García T. (2006), Aplicació de L’Assaig Barcelona pel Control del Formigó Reforçat amb Fibres U tilitzat en la Construcció d'un Edifici Industrial Projecte de Fi de Carrera Enginyer en O rganització Industrial, Escola Tècnica Superior d’Enginyeria Industrial de Barcelona, U niversitat Politècnica de Catalunya, Barcelona, España, 94 pp.

G ettu R. y Barragán B. (2003), Direct tension test and interpretation. Proceeding of the Rilem TC 162-TDF. W orkshop. Editado por B. Schnütgen y L Vanderwalle, pp 15-30.

Gopalaratnam V. y G ettu R. (1995), O n the Characterization of Flexural Toughness in Fiber Reinforced Concrete. Int. Journal Cement and Concrete Composites. Vol. 17, pp 239 - 254.

Guardia J. y M olins C. (2008), Caracterizació del Comportament a Tracció del Formigó D ’Alta Traballabilitat Reforçat amb Fibres D'Acer M itjançant L'Assaig Barcelona. 2008-PI-01, Cátedra BMB Innovación en tecnología del hormigón. Publicacions del Dept. d'Enginyeria de la construcció, Barcelona, 290 pp.

IN N (1977), Hormigón - Ensayo de Tracción por Hendimiento, Instituto Nacional de Normalización, Santiago de Chile, $5 \mathrm{pp}$.

JSCE (1984 a), SF - 4, M ethod of Test for Flexural Strength and flexural Toughness of Fiber Reinforced concet, JCI Standard SF 4, Japan Society of Civil Engineers, Tokyo, Japón, pp 45 - 51.

JSCE (1984 b), SF - 5, M ethod of Test for Compressive Strength and Compressive Toughness of Steel Fibre Reinforced Concrete, Recommendation for Design and Construction of Steel Fibre Reinforced Concrete. Japan Society of Civil Engineers, Tokyo, Japón, pp 63 - 66.

Linsbauer H.N . y Tschegg E.K. (1986), Fracture Energy Determination of Concrete with Cube Shaped Specimens. Zemenet und Beton, Vol. 31, pp $38-40$.

Löfgren I., Stang H. y O lesen J.F. (2004), Wedge Splitting Test - A Test to Determine Fracture Properties of FRC. 6th RILEM Symposium on FRC-BEIFIB, Varenna. Italia, pp 379 - 388.

Marti P. (1989), Size Effect in Double-Punch Tests on Concrete Cylinders. ACI Materials Journal, Vol. 86, p. 597-601.

Molins C., Aguado A., Saludes S. y Garcia T. (2007), New Test to Control Tension Properties of FRC. ECCO MAS Thematic Conference on Computational M ethod in Tunnelling (EURO:TUN 2007), Editado por J. Eberhardsteiner et al., Viena, Austria, 27 - 29 agosto de 2007, Vol. 1, 11 pp.

M olins C., Aguado A. y Guàrdia T. (2008a), Control de la Resistencia a Fisuración y Tracción Residual de HRFA M ediante el Ensayo Barcelona, IV Congreso ACHE - Congreso Internacional de Estructuras, Valencia, 24 - 27 noviembre de 2008, Vol. 1, $10 \mathrm{pp}$

M olins C., Aguado A. y Saludes S. (2008b), D oble PunchTest to Control the Tensile Properties of FRC (Barcelona Test). Material and Structures. Accepted 13 may 2008.

Mora F. (2008), Distribución y O rientación de Fibras en Dovelas, Aplicando el Ensayo Barcelona Tesis Doctoral, ETSECCPB, U niversitat Politècnica de Catalunya, Barcelona, España, 428 pp.

Nanni A. (1988), Splitting - Tension Test for Fiber Reinforced Concrete, ACl Material Journal, Vol 85, pp 229 233.

Nanni A. (1991), Pseudoductility of Fiber Reinforced Concrete, ASCE Journal Structural Engineering, Vol 117, 78 90. 
N BN B 15-238 (1992), “Test on Fibre Reinforced Concrete - Bending Test on Prismatic Simples". Norme Belge, Institut Belge de Normalisation, Brussels.

Rilem (1994), Tension Splitting of Concrete Specimen CPC6, 1975, Rilem Technical Recommendation for the Testing and U se of Construction Materials, E \& FN Spon, London, pp 21 - 22.

Rilem (2002), TC-162 TDF Test and Design M ethods for Steel Fibre Reinforced Concrete: Bending Test. M aterials and Structures, Vol. 35, p. 579-582.

Saludes S., Aguado A. y M olins C. (2007), Ensayo de doble punzonamiento aplicado al hormigón reforzado con fibras (Ensayo Barcelona). Cátedra BM B Innovación en tecnología del hormigón. 1 ed. Barcelona: Publicacions del Dept. d'Enginyeria de la construcció. $338 \mathrm{pp}$.

Zepeda Y. (2008), Implementacion del Ensayo Barcelona Para Hormigones Reforzados Con Fibra, Memoria de titulación para optar al título de Constructor Civil, Universidad Técnica Federico Santa María, Valparaíso, Chile, $64 \mathrm{pp}$. 